\title{
Tectonic and neotectonic implications of a new basement map of the Lower Tagus Valley, Portugal
}

\author{
João Carvalho a,*, Taha Rabeh ${ }^{\mathrm{b}}$, Rui Dias ${ }^{\mathrm{c}}$, Ruben Dias ${ }^{\mathrm{a}}$, Carlos Pinto ${ }^{\mathrm{a}}$, Tomás Oliveira ${ }^{\mathrm{a}}$, \\ Teresa Cunha ${ }^{a}$, José Borges ${ }^{c}$ \\ a Laboratório Nacional de Energia e Geologia, Apartado 7586, 2721-866 Amadora, Portugal \\ ${ }^{\mathrm{b}}$ National Research Institute of Astronomy and Geophysics, Helwan, Cairo, Egypt \\ c Centre of Geophysics of Évora, University of Évora, Évora Portugal
}

\section{A R T I C L E I N F O}

\section{Article history:}

Received 25 July 2013

Received in revised form 23 December 2013

Accepted 14 January 2014

Available online 23 January 2014

\section{Keywords:}

Basement

Magnetic interpretation

Seismic reflection interpretation

Well and geological outcrop data

Tectonics

Seismicity

\begin{abstract}
A B S T R A C T
In this paper we present a new basement (defined here as Paleozoic, Precambrian and Mesozoic igneous rocks) map of the Lower Tagus Valley area. This map is a contribution to the understanding of the structural evolution of the top of the basement in the Lower Tagus Valley area during the Mesozoic and Cenozoic Eras. The map was produced using aeromagnetic, well, seismic reflection and geological outcrop data. It shows unprecedented details of the geometry of the basement rock's surface with higher resolution and covers a larger area than the previous basement map of the study area. In spite of an estimated average error of $200 \mathrm{~m}$ in depth and an horizontal resolution of $4 \mathrm{~km}$, our map not only reproduces with accuracy several well known basement structures but it also emphasizes previously unknown features. Major basement faults were inferred from large depth variations at the top of the basement, magnetic 2D Euler deconvolution and horizontal gradient analysis and are compatible with surface geological structures, well data and hydrogeological information. Implications to the geodynamic evolution of the SW European Variscides and consequences to Meso-Cenozoic tectonics are discussed. The correlation of the basement structures with instrumental seismicity is carried out and their neotectonic activity is discussed on the basis of existing geological outcrop data.
\end{abstract}

(C) 2014 Elsevier B.V. All rights reserved.

\section{Introduction}

Basement maps of the Lower Tagus Valley evidence the presence of pre-Mesozoic igneous and metamorphic units. The mapping of the basement top is important to understand the tectonic and structural evolution of the basement units and the upper geologic units. From basin analysis often result implications with an important scientific impact in many areas.

The results of the top of the basement surface map analysis can also help to improve seismic hazard evaluation, once major fault zones in the basement are often the source of historical earthquakes and instrumental seismicity. Moreover, the evolution of previous orogenic events (Variscan Orogeny in the studied domain) can also be better understood because the seismogenic fault zones are often the reworking of the tardi-orogenic fracture network.

Top of the basement maps are also important from the economic point of view. For example, the accumulations of hydrocarbons or the location of potential sites for geothermal exploration depend on

\footnotetext{
* Corresponding author at. LNEG, Estrada da Portela, Bairro do Zambujal, Apartado 7586-Alfragide, 2610-999 Amadora, Portugal.

E-mail address: joao.carvalho@Ineg.pt (J. Carvalho).
}

basement depth. Indeed, the depth of the sedimentary cover/basement boundary has a strong influence on the temperatures reached in the basin which are important indicators to evaluate the hydrocarbon maturation and/or geothermal exploration.

Where the basement is covered by a thick sedimentary cover, mapping of the top of the basement surface is usually done by the combination of well and seismic data. For large areas or where this data are not available, drilling is too expensive to be practical and potential-field data can be very useful for this task. This is the case for the study area and therefore we produced a top of the basement map for the Lower Tagus Valley and adjacent areas using seismic reflection and well data where available and potential-field data for the areas with no seismic coverage. Fig. 1 shows the location of the study area, sited in central Portugal mainland.

Potential-field data are often used to produce top of the basement maps. Gravity data are not always adequate to obtain the depth of the basement (in the sense defined above). In regions covered by Cenozoic sediments, as in a large part of the study area, the gravimetric "basement" corresponds to the top of the boundary with Mesozoic rocks (e.g. Carvalho et al., 2011a); indeed, the density contrast between Cenozoic and Mesozoic/Paleozoic rocks is larger than the contrast between Mesozoic and Paleozoic rocks (Carvalho et al., 2011a). Consequently, 